\title{
Laju Pengeringan Kentang Kering (Solanum tuberosum L.) dengan Menggunakan Tunnel Dehydrator
}

\section{Dehidrated Potatoes Drying Rate (Solanum tuberosum L.) Using Tunnel Dehydrator}

\author{
Hisworo Ramdani ${ }^{1,2^{*}}$ dan Jerico Naikisa ${ }^{1}$ \\ ${ }^{1}$ Program Studi Ilmu dan Teknologi Pangan, Fakultas Bioindustri, Universitas Trilogi, Jakarta, Indonesia \\ ${ }^{2}$ Pusat Kajian Hortikultura Tropika (PKHT) Institut Pertanian Bogor, Kampus IPB Baranangsiang \\ Jl. Raya Pajajaran Bogor, Indonesia
}

Diterima 20 Januari 2019/Disetujui 22 Februari 2019

\begin{abstract}
The purpose of this study is to obtain the drying rate of dry potatoes that have the best color quality and moisture content by treating the temperature and size of the potatoes tested. This drying uses a Tunnel Dehydrator to get a combination of temperature and size treatment of potatoes by color analysis and water content to get the best treatment and drying rate. The results of this study get the drying rate $y=-0.013 x+5.0433$ and the coefficient of determination $\left(R^{2}\right)$ of 0.9539 or $95.39 \%$ with the best drying treatment at a temperature of $70{ }^{\circ} \mathrm{C}$ with potato thickness $1 \times 1 \times 1 \mathrm{~cm}$, yield $14.1 \%$, moisture content $10.26 \%$ and chroma value 23.35 (very good).
\end{abstract}

Keywords : dehydrated potatoes, dry potatoes, drying rate, tunnel dehydrator

\section{ABSTRAK}

Tujuan Penelitian ini yaitu untuk mendapatkan laju pengeringan kentang kering yang memiliki kualitas warna dan kadar air terbaik dengan perlakuan suhu dan ukuran kentang yang diujikan. Pengeringan ini menggunakan Tunnel Dehydrator untuk mendapatkan kombinasi perlakuan suhu dan ukuran kentang dengan analisis warna dan kadar air untuk mendapatkan perlakuan terbaik dan laju pengeringan. Hasil penelitian ini mendapatkanl aju pengeringan y $=-0.013 x+5.0433$ dan koefisien determinasi $\left(R^{2}\right)$ sebesar 0.9539 atau 95.39\% dengan Perlakuan pengeringan terbaik pada suhu $70{ }^{\circ} \mathrm{C}$ dengan ketebalan kentang $1 \times 1 \times 1 \mathrm{~cm}$,rendemen 14.1\%, kadar air 10.26\% dan nilai chroma 23.35 (baik sekali).

Kata kunci : dehydrated potatoes, kentang kering, laju pengeringan, tunnel dehydrator

\section{PENDAHULUAN}

Indonesia merupakan negara yang memilki kekayaan sumber daya alam yang melimpah terutama pada bidang pertanian yang dapat dipergunakan sebagai sumber pangan bagi masyarakat Indonesia. Pangan merupakan suatu kebutuhan dasar bagi manusia dan berfungsi sebagai sumber energi dan sebagai sumber pangan yang sehat dan bergizi untuk manusia melakukan aktivitas sehari-hari (Persagi, 2009). Pembangunan ketahanan pangan di Indonesia ditujukan untuk menjamin ketersediaan dan konsumsi pangan yang cukup, aman, bermutu, bergizi, dan seimbang pada tingkat rumah tangga, daerah, nasional, sepanjang waktu dan merata (Dewan Ketahanan Pangan, 2010).

Salah satu hasil pertanian pengganti makanan pokok yang akan dibahas dalam penelitian ini adalah kentang. Kentang (Solanum tuberosum) merupakan jenis umbiumbian yang banyak digunakan sebagai sumber karbohidrat dengan memanfaatkan umbi yang dimiliki sebagai produk

\footnotetext{
* Penulis untuk korespondensi. e-mail: ridwanisobir@gmail.com
}

pangan. Menurut Astawan (1991), kentang merupakan umbi-umbian yang cukup menonjol dalam hal penyediaan zat gizi terutama mineral (fosfor, zat besi, dan kalium) serta vitamin B1 dan vitamin C. Hampir semua wilayah di Indonesia dapat ditumbuhi oleh kentang, sehingga produksi kentang di Indonesia pada tahun 2018 mencapai 1.18 juta ton (BPS, 2018) dan mengalami kenaikan sebesar $2 \%$ dari hasil produksi kentang pada tahun 2017.

Kentang dapat dijadikan berbagai macam produk olahan, salah satunya adalah kentang kering (dehydrated potatoes) yang menjadi alternatif dalam memenuhi tuntutan masyarakat terhadap makanan instan. Pengeringan dilakukan sebagai salah satu dari sekian banyak cara pengawetan. Pengeringan merupakan suatu metode untuk mengeluarkan atau menghilangkan sebagian air dari suatu bahan menggunakan energi panas dengan sengaja biasanya dengan cara menguapkan air, bertujuan untuk menurunkan kadar air sampai batas mikroba dan kegiatan enzimatis tidak dapat menyebabkan kerusakan yang berarti. Keuntungan dilakukannya pengeringan, resiko kerusakan sayuran saat pengangkutan menjadi lebih rendah, memiliki umur simpan 
yang lebih lama (mencapai 4 bulan jika menggunakan kemasan plastik polietilen), dan biaya pengangkutan yang lebih murah dibandingkan sayuran yang masih dalam kondisi segar. Asgar (2006) menuturkan bahwa sayuran kering mempunyai prospek yang baik untuk kebutuhan dalam negeri maupun ekspor. Tujuan penelitian adalah untuk mendapatkan laju pengeringan kentang kering yang memiliki parameter suhu dan ukuran kentang terbaik dengan memperhatikan kualitas warna dan kadar air.

\section{BAHAN DAN METODE}

\section{Bahan dan Alat}

Alat yang digunakan dalam penelitian terdiri dari timbangan digital, sealer, pengering tunnel dehydrator, oven dan Color Reader Konica Minolta CR-10. Bahan yang digunakan dalam peneltian terdiri dari kentang, natrium metabisulfit dan air

\section{Metode Penelitian}

Penelitian diawali dengan pengupasan kentang, kemudian dilarutkan di dalam larutan natrium metabisulfit 300 ppm. proses pemotongan kentang berbentuk dadu dengan variasi ukuran yang terdiri dari $1 \times 1 \times 1 \mathrm{~cm} ; 2 \times 2 \times 2$ $\mathrm{cm}$; dan $3 \times 3 \times 3 \mathrm{~cm}$. Pengeringan menggunakan alat tray dryer dengan suhu $50,60,70{ }^{\circ} \mathrm{C}$ selama 4 jam. Pengujian warna dilakukan sebelum dan setelah proses pengeringan dengan menggunakan alat color reader Konica minolta CR-10. Perubahan berat pada kentang dilakukan dengan menimbang bahan setiap satu jam sekali dan pengujian kadar air dengan menggunakan metode oven (Badan Standar Nasional, 1992).

\section{HASIL DAN PEMBAHASAN}

Tunnel dehydratr merupakan mesin pengering berbasis rak yang memiliki pengaturan suhu otomatis dan kontinyu, memiliki 2 buah rak masing-masing berisi 6 tray. Pembuatan Tunnel Dehydrator dirancang dengan ruang pengering yang lebih luas dan menggunakan rak-rak pengering yang tersusun vertikal. Tunnel dehydrator terdiri dari tiga submodel yang cocok untuk memperkirakan keadaan suhunya, dan berhasil dikembangkan dan diterapkan dalam program $\mathrm{C} / \mathrm{C}++$. Suhu pengeringan pada tunnel dehydrator dapat diatur sesuai kebutuhan dan ketepatan suhu ketika proses pengeringan dapat terjaga.

\section{Analisis Kadar Air}

Hasilpengamatanterhadapkadarairterdapatpada Tabel 1 dan Gambar 1. Berdasarkan data pada Tabel 1 diperoleh bahan kentang kadar air tinggi mencapai 86.17\%,. Pengaruh suhu dan ketebalan memberikan pengaruh terhadap kadar air. Apabila pengirisan semakin kecil atau ukuran semakin kecil membuat kadar air juga semakin kecil hal ini dikarenakan luas permukaan mempengaruhi laju penurunan kadar air produk kentang. Faktor yang mempengaruhi kecepatan pengeringan yang maksimum yaitu: luas permukaan bahan, suhu, kecepatan udara, kelembaban udara (RH), tekanan atmosfir dan vakum, serta waktu. Semakin besar suhu yang digunakan maka kecepatan pengeringan akan semakin cepat, sehingga akan mengakibatkan pelepasan air dalam bahan berlangsung cepat.

Tabel 1 dan Gambar 1 menunjukkan bahwa semakin tebal luas permukaan kadar air akan semakin tinggi, dikarenakan air yang berada pada luas permukaan yang lebih besar menampung air yang lebih besar dibandingkan luas permukaan kecil. proses pelepasan air membutuhkan waktu yang panjang. Kadar air terbaik dipengaruhi pada pengaruh ketebalan yang berukuran kecil $(1 \times 1 \times 1 \mathrm{~cm})$ dan pengaruh suhu yang lebih tinggi karena pelepasan air dalam bahan selama empat jam, sehingga bobot pengeringan yang konstan (tetap atau tidak berubah).

\section{Analisis Warna}

Analisis warna dilakukan terhadap bahan dan pada produk perlakuan pengeringan kentang yang dilakukan secara duplo kemudian hasil dirata ratakan. Analisis menggunakan alat color reader Konica Minolta CR-10 dengan menggunakan pemaparan warna dengan sistem yang ditetapkan oleh Komisi Internationale de l'Eclairage (CIE) yaitu ruang warna 1,a,b. Nilai "l" menunjukkan kecerahan sampel, "a" menunjukkan warna merah-hijau, sedangkan

Tabel 1 Hasil analisis kadar air pengeringan kentang

\begin{tabular}{ccccc}
\hline \multirow{2}{*}{ Suhu } & \multicolumn{4}{c}{ Kadar air rata rata (\%) } \\
\cline { 3 - 5 } & Bahan & 1 & 2 & 3 \\
\hline $70^{\circ} \mathrm{C}$ & 86.17 & 12.39 & 44.84 & 48.85 \\
$60^{\circ} \mathrm{C}$ & 85.64 & 18.33 & 46.96 & 65.49 \\
$50^{\circ} \mathrm{C}$ & 85.64 & 23.11 & 53.62 & 73.47 \\
\hline
\end{tabular}

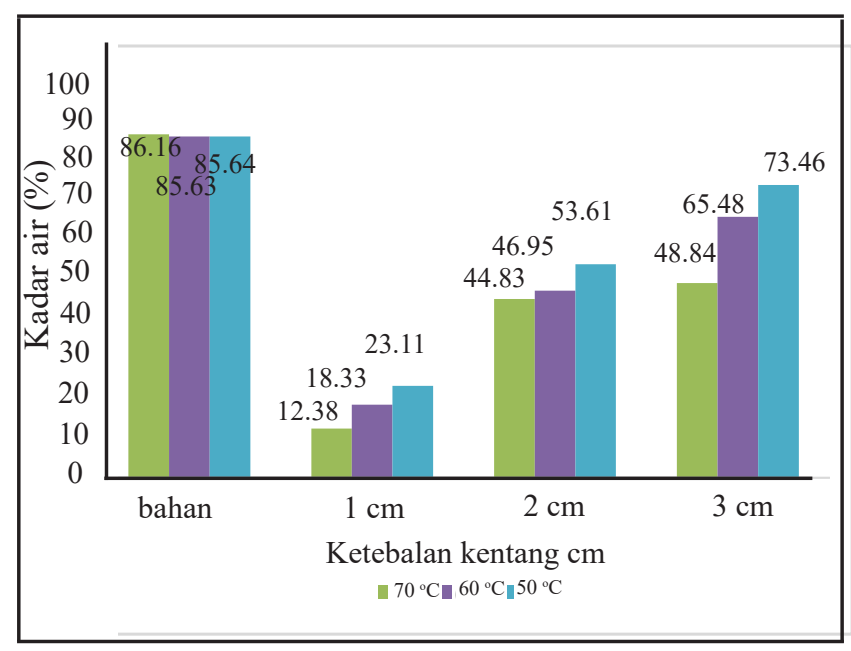

Gambar 1. Kadar air pengeringan kentang 
"b" menunjukkan warna kuning-biru. Hasil pengujian warna terdapat pada Tabel 2. Tingkatan warna dapat diukur dengan menghitung nilai chroma (Las et al. 1996). Nilai c (chroma) merupakan akar dari jumlah kuadrat nilai a dan b. Sanguansri et al. (1993) menyatakan bahwa chroma merupakan ukuran yang paling penting untuk mengetahui tingkatan warna buah-buahan dan sayuran. Nilai chroma yang tinggi pada kentang sangat disarankan karena kentang mempunyai senyawa $\beta$-karoten dan akan mengalami reaksi maillard pada proses pengeringan.

Pada Tabel 2 menunjukan hasil uji warna dengan rata rata perlakuan untuk dua kali ulangan dengan percobaan analisis secara duplo. Kenaikan suhu menyebabkan penurunan kualitas kecerahan bahan (L), hal ini dikarenakan ketika dalam proses pemanasan terjadi reaksi browning secara non enzimatis atau disebut juga dengan reaksi maillard. Menurut Winarno (1997), reaksi maillard adalah reaksi pencoklatan yang terjadi antara karbohidrat khususnya gula pereduksi dengan gugus amina primer. Hasil reaksi tersebut menghasilkan bahan berwarna coklat yang sering tidak dikehendaki atau bahkan menjadi indikasi penurunan mutu.

Nilai $l^{*}$

Perlakuan suhu dan ketebalan kentang memberikan pengaruh pada tingkat kecerahan, dimana semakin besar suhu perlakuan maka tingkat kecerahan akan semakin berkurang intensitasnya hal ini dikarenakan reaksi maillard yang terjadi pada proses pengeringan. Pada penelitian ini tingkat kecerahan yang baik terdapat pada suhu $70{ }^{\circ} \mathrm{C}$ dengan ketebalan 1 x 1 x $1 \mathrm{~cm}$ hal ini dikarenakan pada perlakuan ini tidak jauh berbeda dengan tingkat kecerahan bahannya itu sendiri. Pada suhu $50{ }^{\circ} \mathrm{C}$ tingkat kecerahan cenderung menaik. Hal ini dikarenakan suhu yang terlalu rendah membuat warna kentang lebih memucat sedangkan pada perlakuan $60{ }^{\circ} \mathrm{C}$ terjadi penurunan yang sangat drastis dari bahan. Semakin tinggi nilai $l$ menunjukkan bahwa sampel perlakuan akan cenderung lebih pucat, sebaliknya jika nilai $l$ semakin menurun menunjukan semakin gelapnya warna sampel. Nilai $l$ yang diharapkan yaitu tidak mengalami penurunan ataupun peningkatan yang sangat jauh dari bahan. Jika nilai $l$ terlalu tinggi akan menyabkan warna terlalu pucat karena warna kentang yang diharapkan yaitu warna kuning yang sedikit cerah.

\section{Nilai $a^{*}$}

Nilai a merupakan intensitas warna merah hingga hijau. Berdasarkan Gambar 6 diperoleh bahwa semakin tebal ukuran kentang dan tinggi suhu menyebabkan nilai a semakin tinggi, sedangkan semakin tipis ukuran kentang dan semakin kecil nilai a yang dihasilkan. Nilai a yang semakin kecil akan menujukkan bahwa warna merah semakin berkurang, sedangkan nilai a yang besar menunjukkan nilai merah yang menigkat. Perlakuan suhu dan ketebalan bahan memberikan pengaruh nyata terhadap nilai a. Nilai a pada kentang umumnya memiliki warna kuning dan merah. Warna kuning merah pada produk dipengaruhi reaksi maillard yang terjadi selama proses pengeringan kentang serta adanya pigmen $\beta$-karoten, lutein dan zeaxanthin dalam kentang (Murtiningsih dan Suyanti, 2011).

\section{Nilai $b^{*}$}

Pada Gambar 4 diperoleh bahwa perlakuan suhu dan ketebalan kentang memberikan pengaruh terhadap nilai $b$. Setiap perlakuan mengalami tingkat penurunan derajat warna

Tabel 2. Analisis warna pengeringan kentang dengan color reader Konica Minolta CR-10

\begin{tabular}{|c|c|c|c|c|c|c|c|c|c|}
\hline \multirow{3}{*}{ Perlakuan } & \multirow{3}{*}{ Suhu } & \multirow{3}{*}{ Ukuran } & \multicolumn{3}{|c|}{ Analisis bahan baku } & \multicolumn{4}{|c|}{ Analisis produk } \\
\hline & & & \multicolumn{3}{|c|}{ Warna } & \multicolumn{4}{|c|}{ Warna } \\
\hline & & & $\mathrm{L}$ & $\mathrm{A}$ & $\mathrm{B}$ & $\mathrm{L}$ & A & $\mathrm{B}$ & chroma \\
\hline \multirow[t]{4}{*}{1} & $50^{\circ} \mathrm{C}$ & 1 & 51.9 & 3.43 & 25.9 & 55.5 & 5.5 & 23.8 & 24.44 \\
\hline & & 2 & 51.9 & 3.43 & 25.9 & 53.5 & 5 & 25.6 & 26.03 \\
\hline & & 3 & 51.9 & 3.43 & 25.9 & 56.7 & 5.15 & 25.5 & 25.97 \\
\hline & & Bahan & 51.9 & 3.43 & 25.9 & & & & 26.15 \\
\hline \multirow[t]{4}{*}{2} & $60^{\circ} \mathrm{C}$ & 1 & 50 & 3.8 & 20.7 & 47.2 & 7.6 & 22 & 23.27 \\
\hline & & 2 & 50 & 3.8 & 20.7 & 48.7 & 6 & 19 & 19.9 \\
\hline & & 3 & 50 & 3.8 & 20.7 & 45.8 & 6.7 & 20.3 & 21.32 \\
\hline & & Bahan & 50 & 3.8 & 20.7 & & & & 21.07 \\
\hline \multirow[t]{4}{*}{3} & $70^{\circ} \mathrm{C}$ & 1 & 51.1 & 4.4 & 22.8 & 50 & 4.1 & 19.2 & 19.59 \\
\hline & & 2 & 51.1 & 4.4 & 22.8 & 55.6 & 6.1 & 24.6 & 25.3 \\
\hline & & 3 & 51.1 & 4.4 & 22.8 & 48.9 & 9.5 & 24.3 & 26.11 \\
\hline & & Bahan & 51.1 & 4.4 & 22.8 & & & & 23.24 \\
\hline
\end{tabular}


kuning menuju warna yang sedikit memberikan pengaruh warna biru terhadap kentang. Nilai b yang diharapkan pada kentang memiliki nilai penurunan dan kenaikan, yang disebabkan oleh kondisi ruang yang mempunyai kelembaban relatif $(\mathrm{RH}>25 \%)$. Perubahan warna dapat terjadi disaat penimbangan bahan yang terlalu lama. Penurunan terjadi karena proses pengeringan akan menimbulkan warna semakin kuning, karena adanya pigmen lutein yang terdapat pada kentang.

\section{Nilai Chroma}

Tingkatan warna dapat diukur dengan menghitung nilai chroma. Nilai C (chroma) merupakan akar dari jumlah kuadrat nilai a dan b chroma merupakan ukuran yang paling penting untuk mengetahui tingkatan warna buah-buahan dan sayuran (Sanguansri et al. 1993). Nilai chroma pada produk kentang kering yang dihasilkan bervariasi mulai dari 19.59 sampai dengan 26.15 dengan rata-rata sebesar 23.53. Berdasarkan Sanguansri et al. (1995), nilai-nilai tersebut termasuk ke dalam kelas mutu baik sekali sampai dengan sangat baik sekali seperti pada Tabel 3 .

Nilai chroma yang dihasilkan pada suhu $70{ }^{\circ} \mathrm{C}$ menunjukkan bahwa semakin tipis permukaan kentang membuat nilai chroma menjadi menurun dari kualitas bahan awal, sebaliknya jika semakin tebal permukaan kentang maka nilai chroma menigkat. Hal ini dipengaruhi oleh proses reaksi browning secara non enzimatik yang terjadi pada kentang (reaksi maillard). Hasil perubahan warna sesuai dengan yang diharapkan yaitu warna kuning merah pada produk yang dipengaruhi reaksi maillard yang terjadi selama proses pengeringan kentang serta adanya pigmen $\beta$-karoten, lutein dan zeaxanthin dalam kentang.

\section{Laju Penurunan Bobot}

Perhitungan penurunan bobot pengeringan dilakukan setiap satu jam dengan bobot awal perlakuan sebesar 500 gram. Hasil perhitungan bobot pengeringan terdapat pada Tabel 4, Gambar 2, 3 dan 4. Penurunan bobot kentang selama 4 jam pada perlakuan suhu $50{ }^{\circ} \mathrm{C}$ dan ketebalan kentang $1 \mathrm{x}$ $1 \times 1 \mathrm{~cm}, 2 \times 2 \times 2 \mathrm{~cm}, 3 \times 3 \times 3 \mathrm{~cm}$ mempunyai penurunan bobot yang berbeda. Berdasarkan dengan nilai koefisien determinasi $\left(\mathrm{R}^{2}\right)$ yang diperoleh dari grafik persamaan ini yaitu perlakuan suhu $50{ }^{\circ} \mathrm{C}$ dengan ketebalan bahan $2 \times 2 \times$ $2 \mathrm{~cm}$ yang memberikan pengaruh besar terhadap penurunan bobot dengan nilai koefisien determinasi $\left(\mathrm{R}^{2}\right)$ sebesar

Tabel 3 Klasifikasi mutu berdasarkan nilai chroma

\begin{tabular}{ccc}
\hline Kelas Mutu & Nilai Chroma & Kategori warna \\
\hline 1 & $>20$ & Sangat baik sekali \\
2 & $17-20$ & baik sekali \\
3 & $14-17$ & baik \\
4 & $<14$ & kurang baik \\
\hline
\end{tabular}

0.967 atau $96.7 \%$ dengan persamaan $y=-80.7 x+480.4$. Koefisien determinasi $\left(\mathrm{R}^{2}\right)$ jika nilainya mendekati satu maka dapat dikatakan persamaan tersebut dikategorikan sangat baik. Koefisien determinasi memiliki rentang nilai 0-1. Penurunan bobot pada suhu $50{ }^{\circ} \mathrm{C}$ membutuhkan waktu yang lebih lama untuk mendapatkan bobot konstan (tetap) seperti pada Gambar 2, selisih penurunan bobot pada jam ketiga dan keempat masih mempunyai perbedaan nilai yang cukup signifikan.

Pada Gambar 3 untuk ukuran 1 x 1 x 1 cm menunjukan nilai koefisien determinasi yang rendah tetapi mempunyai penurunan bobot yang mendekati bobot konstan (tetap) pada jam ke 3 dan ke 4 . Hal ini menujukkan bahwa luas permukaan bahan dengan waktu pengeringan selama empat jam pada suhu $60{ }^{\circ} \mathrm{C}$ memberikan pengaruh nyata terhadap perilaku penurunan bobot pada grafik persamaan. Pada Gambar 9 dapat dilihat bahwa koefisien determinasi $\left(\mathrm{R}^{2}\right)$ tertinggi yaitu pada perlakuan kentang ukuran 3 × 3 x $3 \mathrm{~cm}$ sebesar 0.918 atau $91.8 \%$, dan memiliki persamaan linear yang paling baik jika pengeringan dilanjutkan hingga

Tabel 4. Susut Bobot pada Pengeringan Kentang dengan Tunnel Dehydrator

\begin{tabular}{ccccccc}
\hline \multirow{2}{*}{ Suhu } & \multirow{6}{c}{ Ukuran } & \multicolumn{5}{c}{ Susut Bobot pada Pengeringan Jam ke- } \\
\cline { 3 - 7 } & & 0 & 1 & \multicolumn{1}{c}{2} & \multicolumn{1}{c}{3} & \multicolumn{1}{c}{4} \\
\hline $50{ }^{\circ} \mathrm{C}$ & $1 \mathrm{~cm}$ & 500 & 256 & 173 & 118 & 100 \\
& $2 \mathrm{~cm}$ & 500 & 398 & 291 & 221 & 185 \\
& $3 \mathrm{~cm}$ & 500 & 395 & 316 & 270 & 240 \\
$60{ }^{\circ} \mathrm{C}$ & $1 \mathrm{~cm}$ & 500 & 232 & 134 & 98 & 89 \\
& $2 \mathrm{~cm}$ & 500 & 312 & 220 & 170 & 138 \\
$70{ }^{\circ} \mathrm{C}$ & $1 \mathrm{~cm}$ & 500 & 205 & 105 & 83 & 77 \\
& $2 \mathrm{~cm}$ & 500 & 325 & 202 & 160 & 129 \\
& $3 \mathrm{~cm}$ & 500 & 364 & 214 & 198 & 170 \\
\hline
\end{tabular}

Grafik penurunan bobot kentang pada perlakuan suhu $50{ }^{\circ} \mathrm{C}$

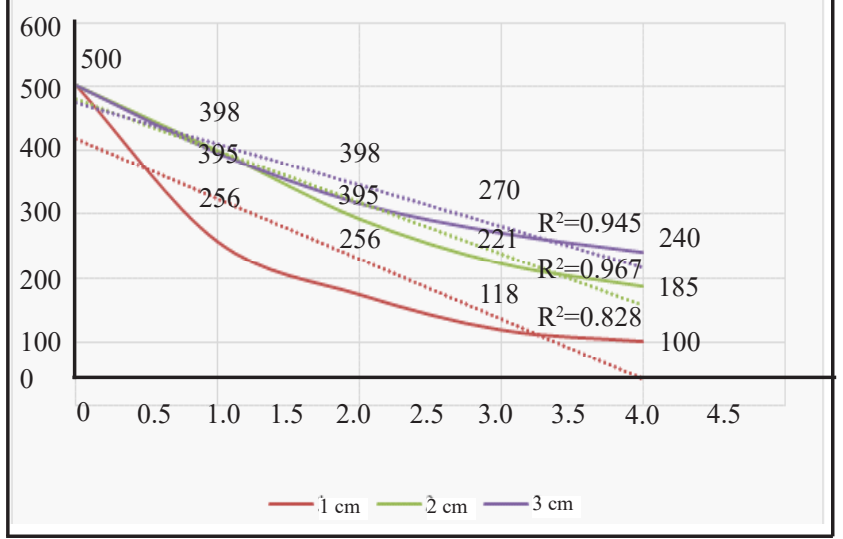

Gambar 2. Penurunan bobot kentang pada perlakuan suhu $50{ }^{\circ} \mathrm{C}$ selama 4 jam 
didapatkan bobot konstan, sedangkan pada ukuran 1 x 1 $\mathrm{x} 1 \mathrm{~cm}$ memiliki nilai penurunan bobot yang mendekati penurunan konstan. Oleh sebab itu diperlukan lama pengeringan yang lebih dari empat jam untuk memperoleh bobot konstan dan lama waktu terbaik untuk perlakuan suhu $60{ }^{\circ} \mathrm{C}$.

Pada Gambar 4 untuk ukuran 1 x 1 x 1 cm mempunyai nilai koefisien determinasi yang rendah tetapi mempunyai penurunan bobot yang mendekati bobot konstan (tetap) pada jam ke 3 dan ke 4. Hal ini menujukkan bahwa luas permukaan bahan dengan waktu pengeringan selama empat jam pada suhu $70{ }^{\circ} \mathrm{C}$ memberikan pengaruh nyata terhadap perilaku penurunan bobot pada grafik persamaan. Pada gambar 6 dapat dilihat bahwa koefisien determinasi $\left(\mathrm{R}^{2}\right)$ tertinggi yaitu pada perlakuan kentang ukuran 3 x 3 x $3 \mathrm{~cm}$ sebesar 0.918 atau $91.8 \%$. dan memiliki persamaan linear yang paling baik jika pengeringan dilanjutkan hingga didapatkan bobot konstan. Sedangkan pada ukuran 1 x 1 x $1 \mathrm{~cm}$ memiliki nilai penurunan bobot yang mendekati penurunan konstan. Oleh sebab itu diperlukan lama pengeringan yang lebih dari empat jam untuk memperoleh bobot konstan dan lama waktu terbaik untuk perlakuan suhu $70^{\circ} \mathrm{C}$.

\section{Rendemen}

Rendemen merupakan suatu perbandingan jumlah produk yang dikeringkan dengan bahan yang dinyatakan dalam bentuk persen. Hasil analisis rendemen kentang kering terdapat pada Tabel 5. Hasil pengamatan pengeringan kentang dengan menggunakan Tunnel Dehydrator menjelaskan bahwa suhu dan ukuran ketebalan kentang sangat berpengaruh terhadap rendemen. Rendemen sangat dipengaruhi oleh luas permukaan bahan. Semakin besar luas permukaan bahan maka rendemen yang dihasilkan juga semakin besar. Rendemen dipengaruhi oleh suhu. Suhu membantu proses pelepasan air dalam bahan yang menyebabkan bobot air dalam bahan menyusut. Suhu terlalu tinggi akan merusak sistem jaringan bahan kentang yang menyebabkan bobot menyusut.

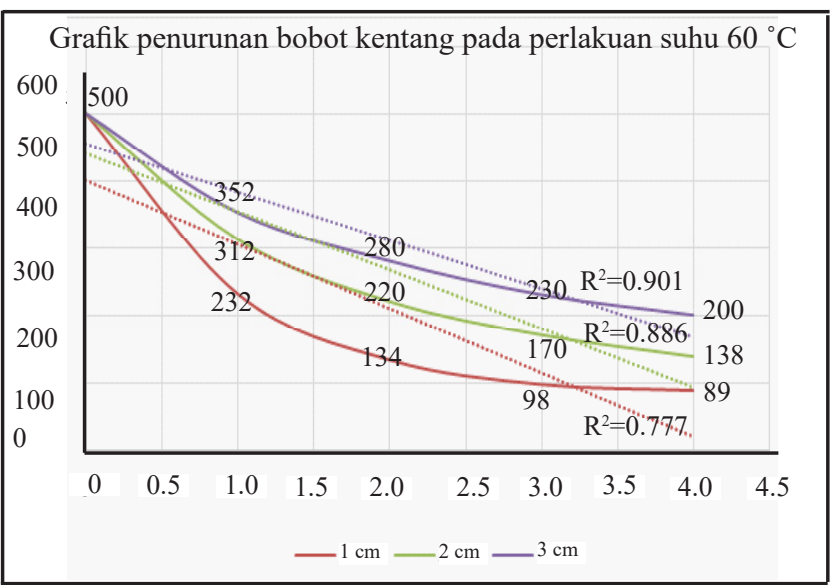

Gambar 3. Penurunan bobot kentang pada perlakuan suhu $60{ }^{\circ} \mathrm{C}$ selama 4 jam

\section{Perlakuan Terbaik}

Perlakuan pengeringan kentang terbaik yaitu pengeringan kentang dengan suhu $70{ }^{\circ} \mathrm{C}$ dan ketebalan bahan 1 x 1 x $1 \mathrm{~cm}$. Hal ini dapat dilihat dari bobot konstan (tetap) dalam lama pengeringan selama 4 jam. Kadar air yang diperoleh dari proses pengeringan tersebut memiliki kadar air terendah. Hal ini dikarenakan pelepasan air pada bahan yang terjadi. Selain itu penentuan perlakuan terbaik juga ditentukan oleh nilai warna. Pengaruh ketebalan kentang dan suhu memberikan pengaruh yang nyata pada analisis warna. Hasil analisis pada perlakuan terbaik (ketebalan $1 \mathrm{x}$ 1 x 1 dan suhu $70{ }^{\circ} \mathrm{C}$ ) dapat dilihat pada Tabel 6 .

Perlakuan terbaik kentang dianalisis secara fisikokimia kembali. Proses pengeringan dilakukan selama 5 jam dikarenakan perubahan bobot kentang yang konstan. Hal ini menunjukkan proses optimum pengeringan dengan alat tunnel drying pada kentang berukuran 1 x 1 x $1 \mathrm{~cm}$. Kadar air rata - rata produk dan bahan pengeringan kentang ukuran 1 x 1 x 1 pada suhu $70{ }^{\circ} \mathrm{C}$ dengan lama pengeringan selama lima jam yaitu $10.26 \%$ dan $87.62 \%$.

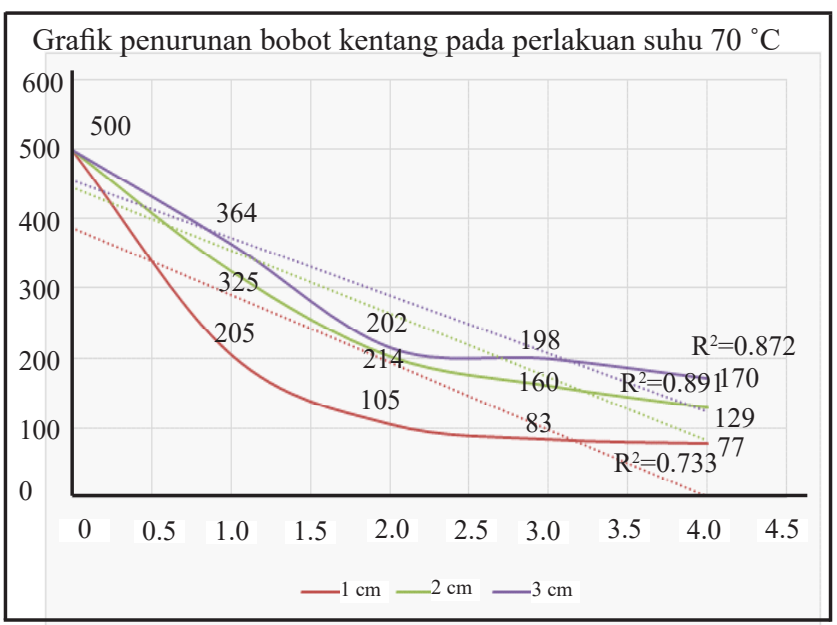

Gambar 4. Penurunan bobot kentang pada perlakuan suhu $70{ }^{\circ} \mathrm{C}$ selama 4 jam

Tabel 5. Pengaruh pengeringan kentang terhadap rendemen

\begin{tabular}{cccc}
\hline Perlakuan & Suhu & Ukuran $(\mathrm{cm})$ & Rendemen $(\%)$ \\
\hline 1 & $50{ }^{\circ} \mathrm{C}$ & $1 \times 1$ & 19.8 \\
& & $2 \times 2$ & 37.9 \\
& & $3 \times 3$ & 49.2 \\
2 & \multirow{2}{*}{$60^{\circ} \mathrm{C}$} & $1 \times 1$ & 17.7 \\
& & $2 \times 2$ & 28 \\
3 & & $3 \times 3$ & 37 \\
& \multirow{2}{*}{$70{ }^{\circ} \mathrm{C}$} & $1 \times 1$ & 15.8 \\
& & $2 \times 2$ & 22.4 \\
& & $3 \times 3$ & 28.1 \\
\hline
\end{tabular}


Laju pengeringan terdapat pada Gambar 5. Semakin lama waktu pengeringan yang dilakukan, maka laju pengeringan akan semakin menurun dengan persamaan $\mathrm{y}=-0.013 \mathrm{x}+5.0433$ dengan koefisien determinasi $\left(\mathrm{R}^{2}\right)$ sebesar 0.9539 atau $95.39 \%$. Laju pengeringan (drying rate, $\mathrm{kg} \mathrm{jam}^{-1}$ ) adalah banyaknya air yang diuapkan tiap satuan waktu atau penurunan kadar air bahan dalam satuan waktu. Krokida et al., melakukan studi pengeringan pada kentang, wortel, jamur dan lainnya. Kadar air dari produk yang dikeringkan menurun seiring dengan kenaikan temperatur. Temperatur dan lama pengeringan merupakan faktor yang paling mempengaruhi dalam laju pengeringan.

Hasil analisis terhadap bobot pengeringan (Tabel 4) menunjukkan bahwa pengeringan pada jam ke 3-5 mengalami penurunan bobot yang tidak berbeda jauh (konstan). Penurunan massa objek cenderung stabil pada akhir durasi penelitian pada temperatur yang tinggi, hal ini disebabkan kandungan air pada kentang sangat sedikit sehingga sudah tidak ada lagi air yang bisa diuapkan pada kentang.

Analisis terhadap warna (Tabel 4) menunjukkan bahwa nilai 1 , a, dan b mengalami kenaikan yang signifikan dari awal bahan, berbanding terbalik dengan penelitian pendahuluan. Pemberian natrium metabisulfit sebesar 300 ppm pada saat proses blanching, sehingga menurunkan warna, tetapi nilai chroma yang diperoleh sebesar 24.37 yang menunjukkan mutu warna yang sangat baik sekali.

Analisis rendemen terdapat pada Tabel 7. Rendemen yang dihasilkan dengan membagi bobot akhir dengan bobot awal dikali dengan seratus persen. Rendemen pengeringan kentang dengan menggunakan Tunnel Dehydrator tergolong kecil, dikarenakan kadar air produk kentang dapat dikategorikan sangat tinggi. Ketika mengalami proses pengeringan, maka akan menyebabkan penurunan bobot dan kadar air dalam bahan.

Tabel 6 Hasil Analisis Terhadap Perlakuan Terbaik

\begin{tabular}{|c|c|c|c|c|c|c|c|c|c|c|c|c|c|c|c|}
\hline \multirow{3}{*}{ Ulangan } & \multirow{3}{*}{ Suhu } & \multirow{3}{*}{ Ukuran } & \multicolumn{9}{|c|}{ Analisis Bahan Baku } & \multirow{2}{*}{\multicolumn{4}{|c|}{$\frac{\text { Analisis produk }}{\text { Warna }}$}} \\
\hline & & & \multicolumn{3}{|c|}{ Warna } & \multicolumn{5}{|c|}{ Pengeringan (jam ke- ) } & \multirow[b]{2}{*}{ Kadar air } & & & & \\
\hline & & & $\mathrm{L}$ & A & B & 1 & 2 & 3 & 4 & 5 & & $\mathrm{~L}$ & A & B & $\mathrm{C}$ \\
\hline \multirow[t]{2}{*}{1} & $70^{\circ} \mathrm{C}$ & 1 & 50.50 & 2.90 & 21.85 & 229 & 89 & 77 & 70 & 70 & 9.56 & 62 & 4.45 & 23.60 & 24.01 \\
\hline & & Bahan & 50.50 & 2.90 & 21.85 & & & & & & 88.00 & & & & \\
\hline \multirow[t]{2}{*}{2} & $70^{\circ} \mathrm{C}$ & 1 & 50.50 & 2.90 & 21.85 & 180 & 83 & 73 & 72 & 71 & 10.96 & 58.95 & 6.20 & 23.95 & 24.73 \\
\hline & & Bahan & 50.50 & 2.90 & 21.85 & & & & & & 87.24 & & & & \\
\hline
\end{tabular}

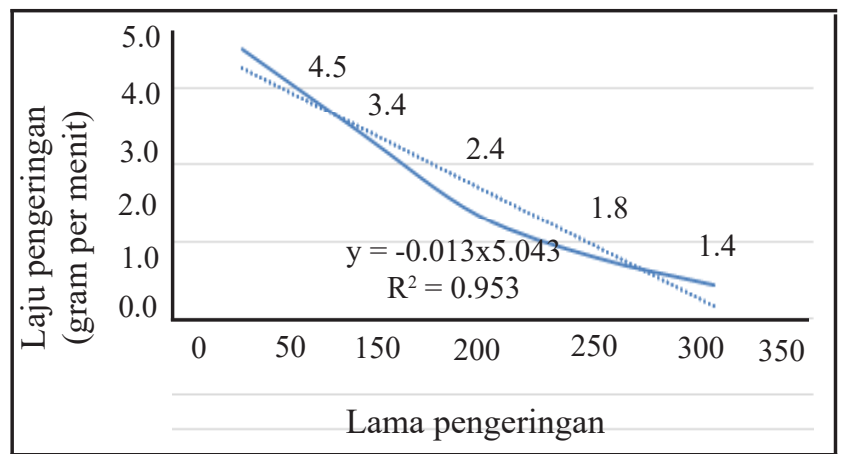

Gambar 5. Grafik lama pengeringan terhadap laju pengeringan kentang

Tabel 7 Rendemen pada perlakuan terbaik

\begin{tabular}{ccccccc}
\hline \multirow{2}{*}{ Ulangan } & \multicolumn{5}{c}{ Lama Pengeringan } & \multirow{2}{*}{ Rendemen } \\
\cline { 2 - 6 } & 60 & 120 & 180 & 240 & 300 & \\
\hline 1 & 229 & 89 & 77 & 70 & 70 & 14 \\
2 & 180 & 83 & 73 & 72 & 71 & 14.2 \\
\hline Rata-rata & \multicolumn{1}{c}{} \\
\hline
\end{tabular}

\section{KESIMPULAN}

Laju pengeringan kentang kering pada penelitian ini yaitu $y=-0.013 x+5.0433$ dengan koefisien determinasi $\left(R^{2}\right)$ sebesar 0.9539 atau $95.39 \%$ dengan Perlakuan pengeringan terbaik yaitu pada suhu $70{ }^{\circ} \mathrm{C}$ dengan ketebalan kentang 1 x 1 x $1 \mathrm{~cm}$. Rendemen yang dihasilkan pada pengeringan kentang sebesar $14.1 \%$ dan kadar air $10.26 \%$ dengan nilai chroma 23.35 (baik sekali).

\section{DAFTAR PUSTAKA}

Asgar, A., D. Musadadd. 2006. Pengaruh Media, Suhu, dan Lama Blansing Sebelum Pengeringan terhadap Mutu Lobak Kering. Jurnal. Balai Penelitian Tanaman Sayur. Bandung.

Astawan, M., A. Wahyuni. 1991. Teknologi Pengolahan Pangan Nabati Tepat Guna. Akademi Prassindo. Jakarta.

[BPS] Badan Pusat Statistik 2018. Statistik Pertanian Indonesia 2018. Badan Pusat Statistik. Jakarta. 
Badan Standarisasi Nasional. 1992. SNI 01-2891-1992. Cara Uji Makanan dan Minuman.

Dewan Ketahanan Pangan. 2010. Kebijakan Umum Ketahanan Pangan 2010- 2014. Jakarta.

Krokida, M.K., V. Oreopolou, Z.B. Maroulis, D. Marinos. 2001. Colourchanges during deep far frying. J Food Eng. 48: 219-225.

Las, I., A. Unadi, F. Agus. 1996. Consept Note: Sistem Pertanian Efisien Karbon. Monograf. Balai Besar Litbang Sumberdaya Lahan (BBSDLP). Badan Litbang Pertanian.

Murtiningsih, Suyanti. 2011. Membuat Tepung Umbi dan Variasi Olahannya. AgroMedia Pustaka. Jakarta.
Persagi. 2009. Labu kuning, Daftar Komposisi Bahan Makanan. DKBM, Jakarta.

Sanguansri, L,. M. Foster, P. Drew, N. Guirguis, I. Gould. 1993. Feasibility studies on processing tomato waste and dry tomato product. Report for The Australian Processing Tomato Research Council and The Horticultural Research and Development, Australian Food Industry Science Centre, Werribee, Victoria.

Sanguansri, L., M. Foster, P. Drew, N. Guirguis, I. Gould. 1995. Improved Quality for Dry Tomatoes. Final Report No. TM-304, Australian Food Industry Science Centre. Weriebe, Victoria.

Winarno, F. G. 1997. Kimia Pangan dan Gizi. Gramedia Pustaka Utama. Jakarta. 